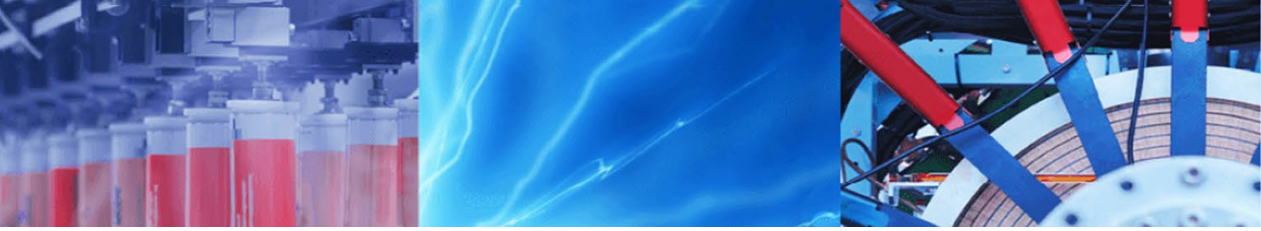

Research Article

\title{
Optimization of copper removal from wastewater by fly ash using central composite design of Response surface methodology
}

\author{
Soumitra Maiti ${ }^{1,2} \cdot$ Basheshwer Prasad $^{1} \cdot$ Ashwani Kumar Minocha $^{2}$
}

Received: 2 June 2020 / Accepted: 12 November 2020 / Published online: 4 December 2020

(c) Springer Nature Switzerland AG 2020

\begin{abstract}
This study aimed to investigate the possibility of utilizing a locally available fly ash as a low-cost adsorbent material for the removal of copper from aqueous solution. Though copper is an essential element, it can be poisonous to human beings at higher concentrations. The removal efficiency of copper is studied under the different initial concentrations of copper (20-50 mg/L), pH (2-6), and fly ash dosage (20-80 g/L). A second-order polynomial model is proposed to study the interactive effects of the parameters. The result of the analysis of variance (ANOVA) confirms the quadratic model is very significant. The optimization of the process variables is carried out by using a full factorial rotatable Central Composite Design (CCD) in Response Surface Methodology (RSM) by Design-Expert Software (Version 6.0.8, State Ease, USA). The maximum removal of copper is achieved at an initial copper concentration of $43 \mathrm{mg} / \mathrm{L}, \mathrm{pH} 6$, and fly ash dosage $63 \mathrm{~g} / \mathrm{L}$. The value of the determination coefficient $\left(R^{2}\right)$ is found to be 0.9945 . The value of Prob $>F$ of the developed model is $<0.0001$, indicating the applicability of the model. The fly ash has been analyzed by XRD, DTA, FTIR, and SEM/ EDS techniques. The results of this study indicate that this fly ash can be used as a low-cost adsorbent to treat acidic wastewater generated from industries like electroplating, fertilizer, copper smelting, acid mine drainage, etc.
\end{abstract}

Keywords Central composite design · Copper · Fly ash · FTIR · Optimization · Response surface methodology · SEM/EDS

\section{Introduction}

Removal of heavy metals from wastewater is one of the most challenging environmental problems faced by several researchers worldwide. Unlike other organic pollutants, heavy metals' degradation rate is very slow; thus, these metals become a part of the food chain and accumulated in a living organism's body. Some of these heavy metals are very toxic, even in low concentrations. For example, exposer of copper above $1.3 \mathrm{mg} / \mathrm{L}$ for short periods of time causes intestinal and stomach problems [1]. Copper, the metal consider in this study, is widely used in various industrial processes such as electroplating, acid mine drainage, copper smelting, paint, paper factory, printed circuit board, copper smelting, fertilizer industry, etc. The concertation of copper present in these industrial wastewaters is shown in Table 1 [2-8]. Table 1 shows that these industrial wastewaters are the significant contributors of copper to the environment. That's why it is essential to treat copper-containing wastewater before it was discharged into the atmosphere. Though copper is a vital trace nutrient for plants and animals, it can be poisonous to human beings and other living organisms when its concentration is high [9]. Copper is also found as contamination in food such as mushroom, nut, shellfish, etc. A recent study conducted by researchers showed that too much copper consumption throughout life might cause Alzheimer's disease [10]. Because of this reason, the Indian

Soumitra Maiti, soumitra@cbri.res.in | 'Department of Chemical Engineering, Indian Institute of Technology Roorkee, Roorkee, Uttarakhand 247667, India. ${ }^{2}$ Environmental Science \& Technology Group, CSIR-Central Building Research Institute, Roorkee 247667, Uttrakhand, India. 
Table 1 Typical concentration of copper in various industrial wastewaters

\begin{tabular}{lll}
\hline Industrial wastewater & $\begin{array}{l}\text { Average concentration } \\
\text { of copper }(\mathrm{mg} / \mathrm{L})\end{array}$ & References \\
\hline Wood and paper factory & 4.5 & {$[2]$} \\
Fertilizer industry & 198.36 & {$[3]$} \\
Electroplating & $6.25-45$ & {$[4,5]$} \\
Copper mills & $19-800$ & {$[6]$} \\
Plating, brass & $4-44$ & {$[6]$} \\
Acid mine drainage & $0.1-128$ & {$[7]$} \\
Copper smelting & 164.48 & {$[8]$} \\
\hline
\end{tabular}

standard recommends the permissible concentration of copper in drinking water in the absence of an alternative source is $1.5 \mathrm{mg} / \mathrm{L}[11]$.

Several methods are available in the literature to remove heavy metals from wastewater, such as chemical precipitation, solvent extraction, membrane filtration, ion exchange, reverse osmosis, adsorption, etc. As reported by various researchers, coagulation, ion exchange, chemical precipitation, and membrane filtration are the commonly used processes, but this method suffers from the disadvantages, such as expensive chemicals, high energy requirement, high capital and operating cost, and sludge disposal [12-14]. In particular, adsorption is the most wellknown, influential, and economical treatment process for removing these metals from contaminated water. In recent years, several locally available low-cost adsorbent materials such as agricultural waste (olive cake [3], rice straw [4], bagasse ash [15], industrial by-products (red mud [16], fly ash [17-20], slag [21]), and natural materials have been utilized to remove copper from contaminated water. For example, Fernandez-Gonzalez et al. [3] have used a novel hydrolyzed olive cake to remove copper from fertilizer industry wastewater. Singha and Das [4] utilized rice straw to remove copper from electroplating wastewater. Gupta and Ali [15] investigated bagasse coal fly ash's efficiency as a low-cost adsorbent to remove copper and zinc from industrial wastewater. Tsamo et al. [16] studied the adsorption capacity of raw and modified red mud as adsorbents to remove chromium, copper, and lead from contaminated water.

Fly ash, one of the most abundant waste materials from the combustion of coal, is a potential material for the removal of heavy metals present in wastewater. India produces about 130 million tons/yr. of fly ash from the burning of the enormous amount of coal, and by the year 2030 , the fly ash production in India will be about 600 million tons/year [22]. The safe disposal of fly ash is a matter of great concern as it is not environment-friendly and requires a large amount of land to dispose of it in landfills.
It has alkaline properties, and its surface is negatively charged at high $\mathrm{pH}$. That is why it was used as a potential adsorbent for the treatment of wastewater containing heavy metals. Sočo and Kalembkiewicz [17] studied the copper and nickel adsorption properties of coal fly ash by varying the $\mathrm{pH}$, contact time, and initial concentration. The adsorption process followed both Langmuir and Freundlich models. Raw and modified fly ash has been utilized as a potential adsorbent to remove copper from wastewater [18]. The adsorption ability of two different Turkish fly ashes to remove nickel, copper, and zinc from an aqueous solution was investigated by Bayat [19]. It was found the adsorption ability dependent on $\mathrm{pH}$, fly ash origin, and initial metal concentration. Lin and Chang [20] used fly ash having different amounts of carbon and minerals to remove copper from contaminated water. Many researchers also utilized fly ash and modified fly ash to remove copper from wastewater [23-25].

After reviewing the published literature, it is found that copper's adsorption by fly ash is predominantly affected by process parameters such as $\mathrm{pH}$, fly ash dosage, and initial metal concentration. It is, therefore, essential to carefully optimize these process parameters. The majority of adsorption studies emphasized the traditional approach, i.e., one variable at a time (OVAT) approach to optimize these process parameters. But this type of system has several disadvantages, such as it is unable to address the effects of interactions between different factors, and it is also very much time-consuming. Therefore, to overcome these issues, an alternative approach involving statistical design should be considered. RSM technique combines mathematical and statistical methods to develop, improve, and optimize industrial/chemical processes. This technique is beneficial for modeling and analysis of processes where multiple independent variables potentially influence the response. In recent years, RSM techniques have been effectively used for the optimization of the various water treatment process $[26,27]$. Kiran and Thanasekaran [28] employed RSM technique to optimize the copper adsorption capacity of an indigenously developed biosorbent. They have studied the influences of parameters like initial copper concentration, biosorbent dosage, and $\mathrm{pH}$ on copper adsorption. Özer et al. [29] applied the RSM technique combine with CCD to optimize the adsorption of copper by a novel biosorbent. However, no such work has been reported in the literature with the application of the RSM technique to remove copper from wastewater by fly ash.

Accordingly, this work emphasizes optimizing operating parameters to remove copper from wastewater by fly ash using RSM. To study the interactive effect of different operating parameters on copper removal efficiency, RSM combine with CCD of Design-Expert Software is used. The 
results are analyzed to predict the copper uptake, and comparison is made between model prediction data and experimental data. X-ray fluorescence (XRF), FE-Scanning electron microscopy (FE-SEM), X-ray diffraction (XRD), Fourier-transform infrared spectroscopy (FTIR) are used to characterize the fly ash.

\section{Materials and methods}

\subsection{Chemicals}

The following chemicals are used in the experimental work: $\mathrm{NaOH}$ (RFCL, New Delhi), $\mathrm{HCl}$ (Rankem, New Delhi), $\mathrm{Cu}\left(\mathrm{NO}_{3}\right)_{2} \cdot 3 \mathrm{H}_{2} \mathrm{O}$ (Merck, Mumbai), $\mathrm{H}_{2} \mathrm{SO}_{4}$ (RFCL, New Delhi), HF (Merck, Mumbai)

\subsection{Fly ash}

Fly ash used in the present experiment is collected from a coal-based power plant operated by the Hindalco industry located at Renukoot (Uttar Pradesh, India) after receiving relevant permissions for scientific use from the responsible authorities. Before the investigation, the fly ash is washed several times with distilled water and dried at $105^{\circ} \mathrm{C}$ [30]. This dried sample is used throughout the study. The chemical composition of this fly ash is determined by the XRF (Model: Bruker, S8 Tiger Eco) technique. The heavy metals present in the fly ash is analyzed by ICP-optical emission spectrometry (ICP-OES, Model: Prodigy XP, Teledyne Leeman Labs) after hydrofluoric acid digestion of fly ash in a microwave accelerated reaction system (Model: CEM MARS Xpress). The soluble concentration of various heavy metals present in fly ash is also determined to have insight into this fly ash's environmental impact. One gram of fly ash sample is stirred with $200 \mathrm{ml}$ of distilled water for $2 \mathrm{~h}$ and filtered [19]. Then, the heavy metal concentration of filtrate is determined by ICP-OES. The loss on ignition (LOI) of fly ash sample is determined by heating the preweighted air-dried, finely ground sample at $1000 \pm 25^{\circ} \mathrm{C}$ for 20-30 min in a platinum crucible as per IS 1727-1967 [31]. The fly ash sample's specific gravity is determined by Le chatelier flask as per IS 1727-1967 [31]. The surface area of fly ash is determined by Brunauer-Emmett-Teller (BET) method (Model: ASAP 2020 Micromeritics) by nitrogen adsorption isotherm technique. Mineralogical constituent and phase proportions of this fly ash are determined by powder XRD (Model: Bruker, D-8). XRD analysis is carried at room temperature out in the scan rate of $2 \% \mathrm{~min}$ and range of $5-80^{\circ}$ with nickel filter CuKa radiation ( $\lambda=1.54060 \AA$ ) and scanning speed $4 \% \mathrm{~min}$. The XRD pattern is matched with JCPDS and ICSD data files for phase identification. An FE-SEM attached with an energy dispersive spectroscopy is used to study the fly ash sample's surface morphology (Model: Carl Zeiss Ultra Plus). FTIR spectrometer (Nicolet Model Avtar 370Csl, Thermo Electron Corporation) has been utilized to identify the fly ash's functional groups range from 4000 to $500 \mathrm{~cm}^{-1}$. Thermogravimetric analysis (Model: Seiko Exstar 6300) of this fly ash has been carried out under an inert atmosphere (Nitrogen). The particle size of fly ash is determined by the laser scattering technique (Model: Horbia, LA-950).

\subsection{Point of zero charge}

The point of zero charges $\left(\mathrm{pH}_{\mathrm{PZC}}\right)$ of this fly ash is measured by adding $0.5 \mathrm{~g}$ of sample in deionized water $(100 \mathrm{ml})$ in a series of $250-\mathrm{ml}$ conical flask. The slurry's $\mathrm{pH}$ values are adjusted from 2 to 10 by $\mathrm{HCl}(0.1 \mathrm{M})$ or $\mathrm{NaOH}(0.1 \mathrm{M})$. The slurry is agitated continuously for $2 \mathrm{~h}$, and the zeta potential of the slurry has been recorded by a zeta sizer (Model: Malvern Nano ZS90) at different $\mathrm{pH}$ values.

\subsection{Batch study}

The batch study is undertaken for the removal of copper from contaminated water. Stock contaminated water of $1000 \mathrm{mg} / \mathrm{L}$ is prepared synthetically in the laboratory by dissolving cupric nitrate trihydrate salt in deionized water purified by Millipore milli-Q system and standardized [32]. Solutions of different concentrations are prepared by diluting the stock solution. Then, $50 \mathrm{ml}$ of these solutions are mixed with fly ash in a conical flask and placed in a water shaker bath for $3 \mathrm{~h}$ for proper mixing to attain the equilibrium. Batch experiments are conducted in a series of the conical flask containing a variable amount of copper ion and fly ash at different pHs. Then, the samples are taken out of the stirrer and filtered. The filtrate thus obtained is tested for the remaining copper ion concentration using ICP-OES. The removal efficiency of the process is determined by using Eq. 1.

$E=\frac{C_{o}-C_{t}}{C_{o}} \times 100$

The amount of copper adsorbed ( $\mathrm{q} \mathrm{mg} / \mathrm{g}$ ) by fly is calculated by using Eq. 2 .

$q=\frac{\left(C_{o}-C_{t}\right)}{m} \times V$

where $E$ is metal removal efficiency $(\%), C_{o}$ is the initial copper concentration in contaminated water $(\mathrm{mg} / \mathrm{L}), \mathrm{C}_{\mathrm{t}}$ is the final copper concentration in treated water $(\mathrm{mg} / \mathrm{L}), \mathrm{m}$ is the mass of fly ash ( $\mathrm{g}$ ), and V is the volume of solution (L). All the experiments are carried out thrice, and the average values of the results are reported. 


\subsection{Experimental design}

After detailed literature survey it is found that copper removal is predominantly influenced by three independent process variables, namely initial metal concentration, $\mathrm{pH}$, and fly ash dosage. In order to optimize the experimental conditions and to collect data for modeling the ranges of variables are chosen as initial metal concentration (20-50 mg/L), pH (2-6), and fly ash dosage $(20-80 \mathrm{~g} / \mathrm{L})$. A three factorial five-level CCD is developed for this study. For statistical calculations, these parameters $\left(X_{i}\right)$ are coded as $x_{i}$ according to Eq. 3 and shown in Table 2.

$x_{i}=\frac{\left(X_{i}-X_{0}\right)}{\partial x}$

where $x_{i}$ is the coded value, $X_{i}$ is the actual value of the $i$ th process variable, $\partial x$ is the step change, an $X_{0}$ is the value of the process variable at the center point.

For three independent parameters, a total number of experimental combinations are 20 according to $2^{n}+2 n$ +6 . Here, $n$ is the number of independent parameters. This design includes 6 replication at the center point, 6 axial points, and 8 full factorial points.

Data Analysis: The following second-order quadratic polynomial Eq. is employed to attain the interaction between the independent and dependent variables.

$Y=b_{0}+\sum b_{i} X_{i}+\sum b_{i i} X_{i}^{2}+\sum b_{i j} X_{i} X_{j}$

Here, $Y$ is the dependent variable (response i.e., removal efficiency). $X_{i}$ and $X_{\mathrm{j}}$ are the independent process variables $(i=1,2$ and $3 ; j=1,2$ and $3 ; i \neq j)$. $b_{0}$, bi, bii, bij are the constant regression coefficient of the model. Experimental data are evaluated by ANOVA. The quality of the polynomial model's fit is assessed by the value of the determination coefficient $\left(R^{2}\right)$ and adjusted $R^{2}$.

Statistical significance and the adequacy of the employed model are evaluated by the model Fisher variation ratio (F-value), a probability value (Prob $>F)$, and adequate precision value.

\section{Results and discussion}

\subsection{Fly ash characterization}

The physical-chemical properties of the fly ash sample are presented in Table 3. The results specify that this is class F-type fly ash as the combined weight percentage of $\mathrm{SiO}_{2}$ and $\mathrm{Al}_{2} \mathrm{O}_{3}$ is more than $70 \%$ and lime content is less than $10 \%$, according to ASTM C 618 [33]. Fly ash is slightly alkaline as the $\mathrm{pH}$ value of a $2 \%$ aqueous solution is 8.4 . It is evident from Table 3 that the heavy metals present in the fly ash are $\mathrm{Cu}, \mathrm{Cr}, \mathrm{Pb}, \mathrm{Ni}$, and $\mathrm{Mn}$, which constitute a small fraction as compared to other oxides. The soluble concentration of elements present in fly ash is presented in Table 4. The results indicate that the probability of leaching of heavy metals is significantly less, and this fly ash can be classified as non-hazardous waste. Similar observations

Table 3 Physical-chemical characteristics of fly ash

\begin{tabular}{ll}
\hline Element oxide & Weight (\%) \\
\hline $\mathrm{SiO}_{2}$ & 55.8 \\
$\mathrm{Al}_{2} \mathrm{O}_{3}$ & 23.9 \\
$\mathrm{Fe}_{2} \mathrm{O}_{3}$ & 5.2 \\
$\mathrm{SO}_{3}$ & 3.4 \\
$\mathrm{Na}_{2} \mathrm{O}$ & 2.9 \\
$\mathrm{~K}_{2} \mathrm{O}$ & 2.1 \\
$\mathrm{TiO}_{2}$ & 1.9 \\
$\mathrm{CaO}$ & 1.2 \\
$\mathrm{Concentration}$ of elements in fly ash in $\mathrm{mg} / \mathrm{kg}$ & \\
$\mathrm{Cu}$ & 10 \\
$\mathrm{Cr}$ & 12 \\
$\mathrm{Zn}$ & 32 \\
$\mathrm{~Pb}$ & 9 \\
$\mathrm{Ni}$ & 18 \\
$\mathrm{Mn}$ & 21 \\
$\mathrm{Physical}$ Properties & \\
pH & \\
Loss on ignition & 8.4 \\
Specific gravity & $2.8 \%$ \\
Specific surface area (m & \\
\hline & 2.62 \\
\hline
\end{tabular}

Table 2 Experimental range and coded levels of process variables

\begin{tabular}{|c|c|c|c|c|c|c|}
\hline \multirow[t]{2}{*}{ Independent process variables } & \multicolumn{5}{|c|}{ Coded levels } & \multirow{2}{*}{$\begin{array}{l}\text { Step } \\
\text { change } \\
\text { value }\end{array}$} \\
\hline & -2 & -1 & 0 & 1 & 2 & \\
\hline & \multicolumn{5}{|c|}{ Actual values } & \\
\hline Initial copper concentration (mg/L) $\left(X_{1}\right)$ & 20 & 27.5 & 35 & 42.5 & 50 & 7.5 \\
\hline $\mathrm{pH}\left(\mathrm{X}_{2}\right)$ & 2 & 3 & 4 & 5 & 6 & 1 \\
\hline Fly ash dosage $(\mathrm{g} / \mathrm{L})\left(\mathrm{X}_{3}\right)$ & 20 & 35 & 50 & 65 & 80 & 15 \\
\hline
\end{tabular}


Table 4 Soluble concentrations of some elements present in fly ash

Fig. 1 Typical particle size distribution curve of the fly ash

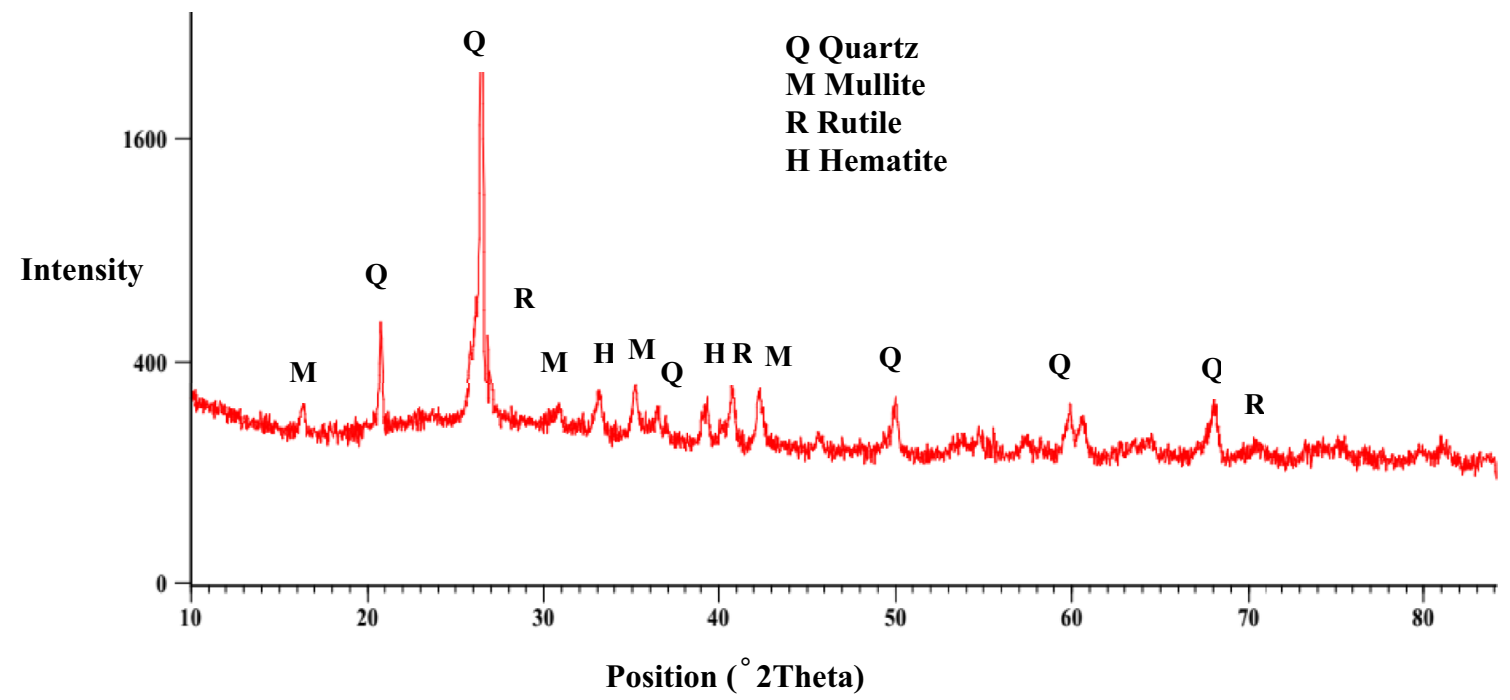

were reported previously by other researchers. [19, 34, 35]. The particle size distribution curve of fly ash is presented in Fig. 1. It is found that particle size ranges from 0.389 to $200 \mu \mathrm{m}$. It is also observed that $90 \%$ of the particles are smaller than $81.64 \mu \mathrm{m}$ and $10 \%$ of the particle is smaller than $10.75 \mu \mathrm{m}$. A similar type of particle size distribution curve has also been found in the previous study [36].

The XRD patterns revealed that the fly ash mainly contains Quartz $\left(\mathrm{SiO}_{2}\right)$, a moderate amount of Mullite $\left(\mathrm{Al}_{4.75} \mathrm{Si}_{1.25} \mathrm{O}_{9.63}\right)$, and a meager amount of Rutile $\left(\mathrm{TiO}_{2}\right)$ and Hematite $\left(\mathrm{Fe}_{2} \mathrm{O}_{3}\right)$ (Fig. 2). The individual phases have been matched and analyzed by the PDF-2 database from $X$ 'pert high score plus software. TGA curve shows that mass loss occurs in two stages (Fig. 3 ). In the first stage,

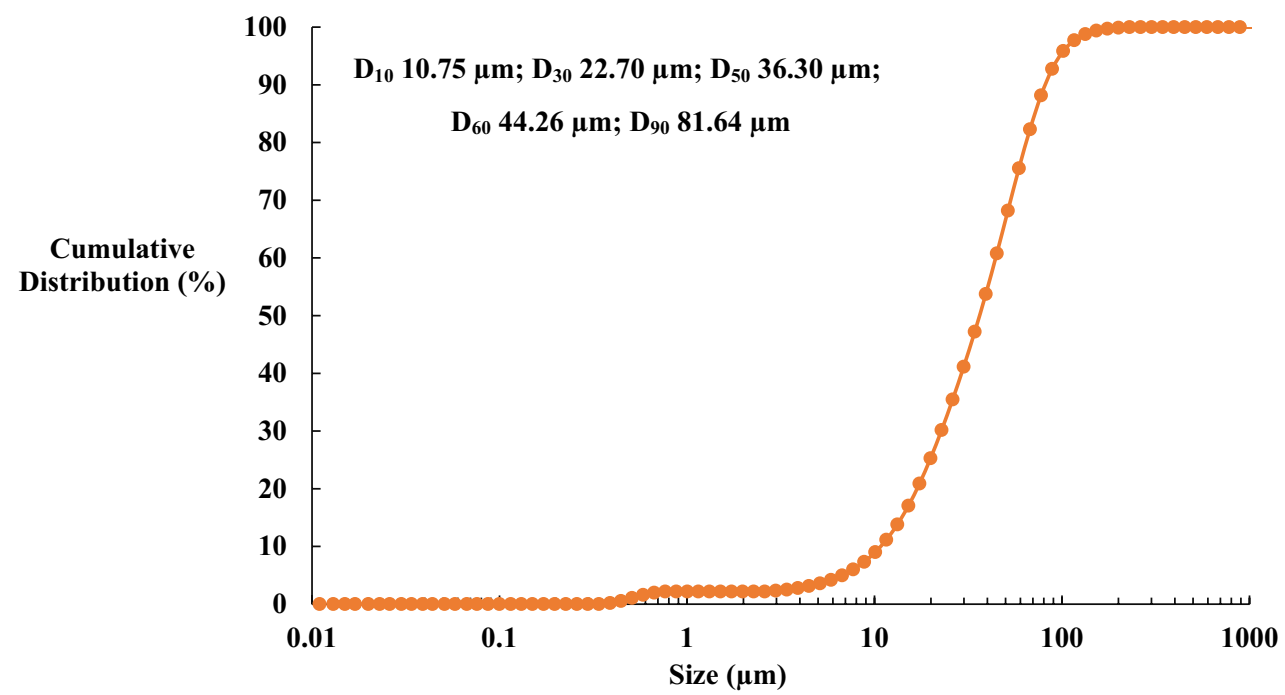

Position ( 2Theta)

Fig. 2 XRD Analysis of fly ash 


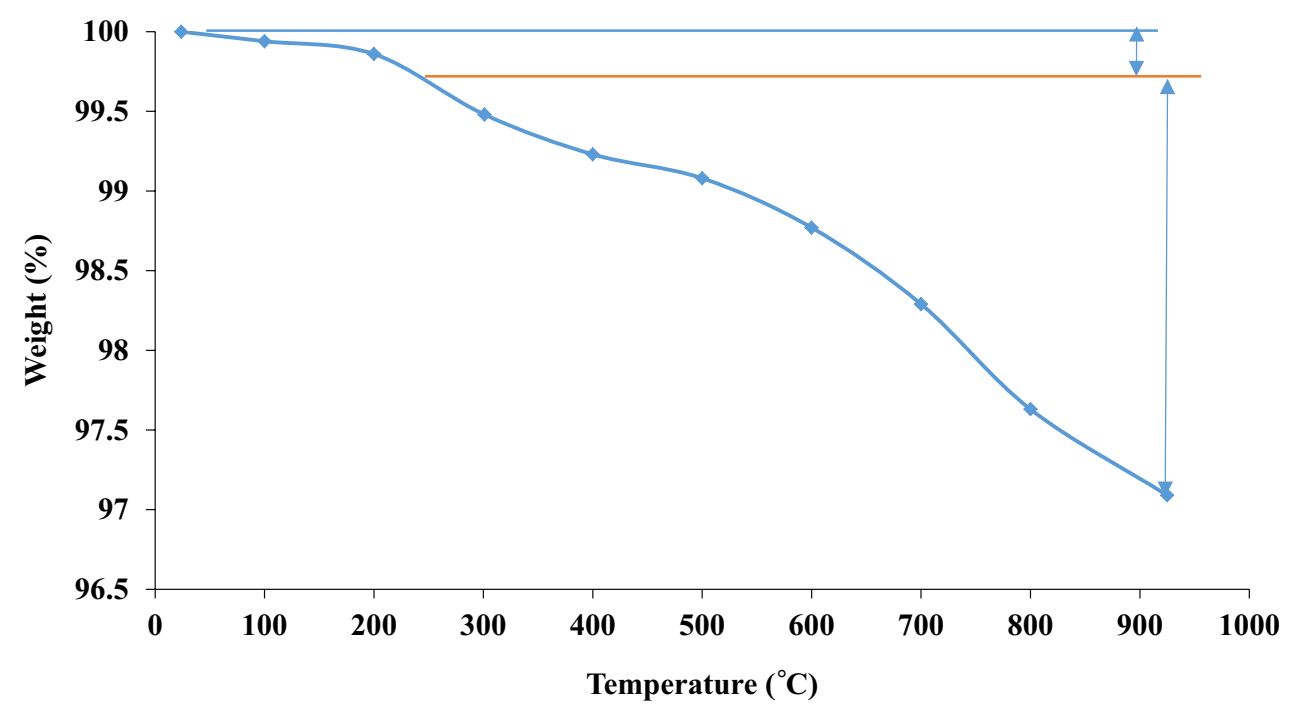

Fig. 3 Thermogravimetric analysis of fly ash

about $0.14 \%$ of mass loss occurs as the sample is heated up to $200^{\circ} \mathrm{C}$. This is maybe due to absorbed moisture and interstitial water in the fly ash. In the second region, $200-925{ }^{\circ} \mathrm{C}$, about $2.8 \%$ of weight loss occurs. This is maybe due to the release of volatile matter from the sample.

$\mathrm{pH}_{\mathrm{PZC}}$ plays a critical role in the adsorption of heavy metal ions. $\mathrm{pH}_{\mathrm{PZC}}$ is the $\mathrm{pH}$ value at which the net surface charge is zero, and the surface of the adsorbent neither exhibits a positive charge nor a negative charge. The zeta potential measurement of this fly ash at different $\mathrm{pH}$ 's is shown in Fig. 4. From the graph, it has been observed that $\mathrm{pH}_{\mathrm{PZC}}$ of this fly ash is 2.9. Researchers have found that the cation's adsorption is favored at a $\mathrm{pH}$ greater than $\mathrm{pH}_{\mathrm{PZC}}$, while an anion is preferred at a $\mathrm{pH}$ lower than $\mathrm{pH}_{\mathrm{PZC}}[37,38]$. The BET surface area of fly ash used in the study is found to be $4.89 \mathrm{~m}^{2} / \mathrm{g}$. [38].

\subsection{SEM/EDS analysis of fly ash before and after adsorption}

Figure $5 a$ and $b$ shows the FE-SEM and EDS analysis result of fly ash before and after adsorption, respectively. From the SEM image, it is clear that the majority of the particles ranged in size from approximately 1 to $100 \mu \mathrm{m}$ and consists of solid spheres. This fly ash contains a considerable number of small flakes (pleurospheres), and the surface is microporous. Regular and spherical shapes of cenospheres are also found. Furthermore, the surface morphology of this fly ash reveals loose aggregates with severely
Fig. 4 Zeta potential of fly ash as a function of $\mathrm{pH}$

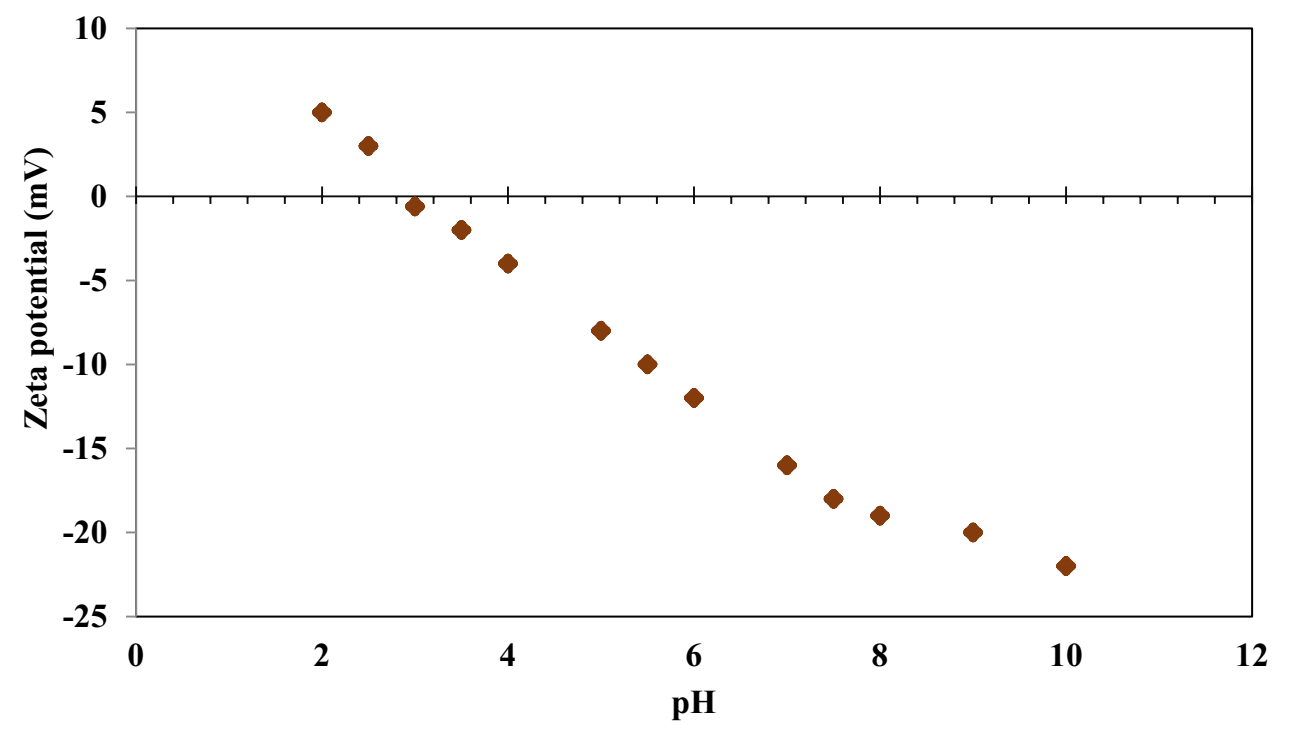



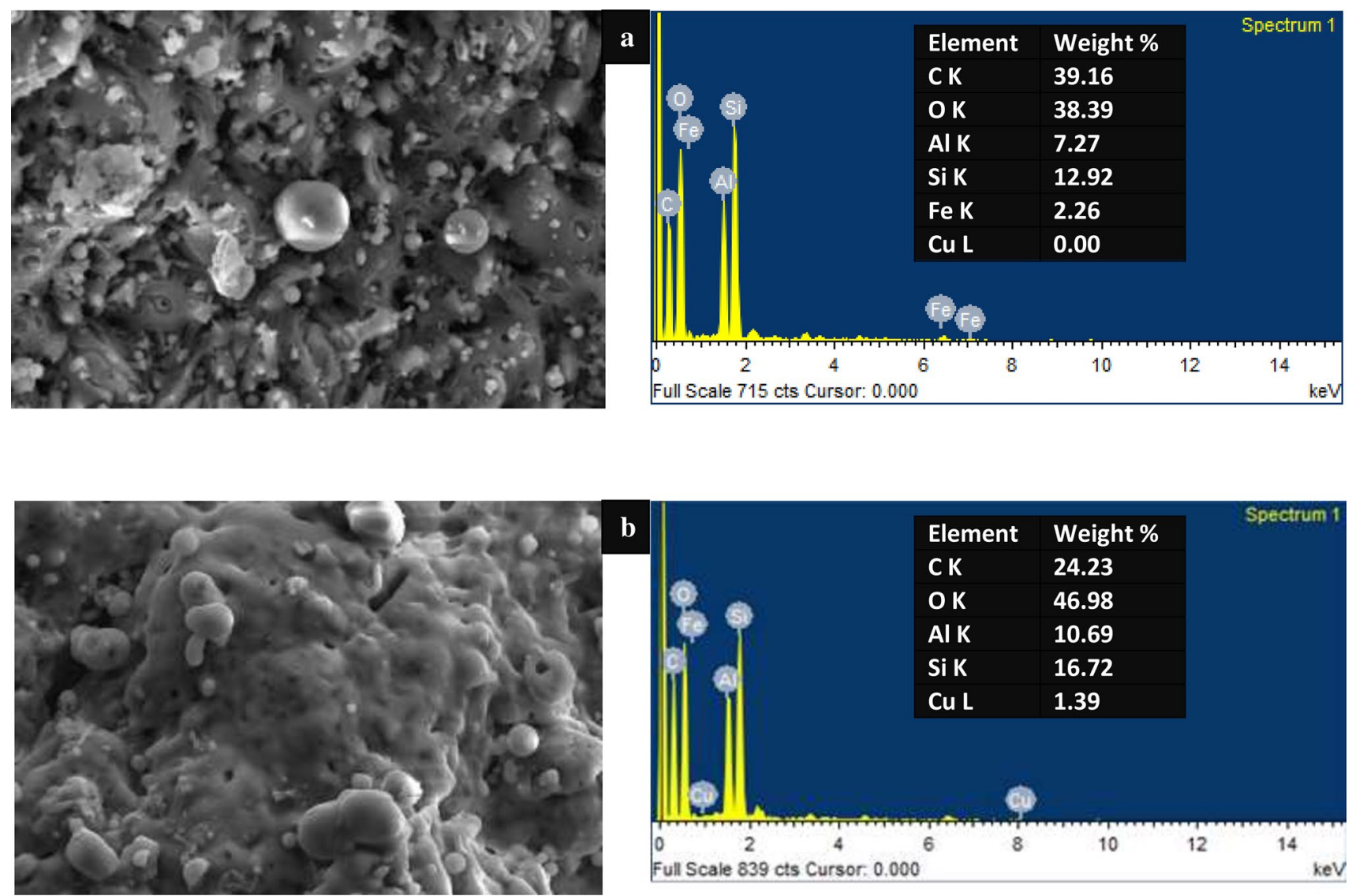

Fig. 5 SEM and EDS analysis of fly ash (a) before adsorption (b) after adsorption

nonuniform layered structures. This microporous structure is responsible for the adsorption of heavy metal ions. When this raw fly ash is used for copper adsorption, the copper ions adsorbed over the fly ash surface and formed a smooth film covering the surface [39]. This film is seen in Fig. 5b. From the EDS analysis, it is clear that before adsorption, copper ion is absent in fly ash surface, but when this fly ash is used for the treatment of wastewater, approximately $1.39 \%$ copper is present on the fly ash surface.

\subsection{FTIR analysis of fly ash before and after adsorption}

Figure 6 shows the FTIR spectra of fly ash before adsorption and after adsorption. In the raw fly ash, a broad band at $3432 \mathrm{~cm}^{-1}$ confirms the hydroxyl group's presence. The bond stretching is due to $\mathrm{O}-\mathrm{H}$ stretching vibration of the silanol group of fly ash $(\mathrm{Si}-\mathrm{OH})$ and $\mathrm{HO}-\mathrm{H}$ vibration of adsorbed water molecules on the fly ash surface. The medium intensity bands at 1646 and $1488 \mathrm{~cm}^{-1}$ are due to $\mathrm{C}=\mathrm{O}$, and $-\mathrm{CH}$ bending vibration. The sharp peak at $1010 \mathrm{~cm}^{-1}$ corresponds to the asymmetric stretching of $\mathrm{T}-\mathrm{O}-\mathrm{T}(\mathrm{T}=\mathrm{Al}, \mathrm{Si})$ tetrahedral sheets. Furthermore, the bands at 798, 684, and $634 \mathrm{~cm}^{-1}$ indicate quartz's presence in the fly ash. It was evident from Fig. 6 that the intensity of spectra differs from raw fly ash, and also the positions of peaks are shifted while fly ash adsorbed copper. The percentage transmittance of the stretching vibration spectra of O-H at $3432 \mathrm{~cm}^{-1}$ is diminished after the adsorption of copper. This is due to the formation of a silanol copper complex as per Eq. 7 [34]. Furthermore, the transmittance of the peaks at $1010,798,684$, and $634 \mathrm{~cm}^{-1}$ are increased after the adsorption of copper. This phenomenon indicates copper is adsorbed on fly ash's active sites (silica and alumina), which results in a decrease in silica and alumina present on fly ash. These results suggested copper is adsorbed on fly ash surface by chemisorption, probably indicating fly ash/copper complexation $[34,40]$.

\subsection{Process modeling and statistical analysis}

The individual and interactive effect of the three process variables (initial metal concentration, $\mathrm{pH}$, and fly ash dosage) on copper removal efficiency are investigated 


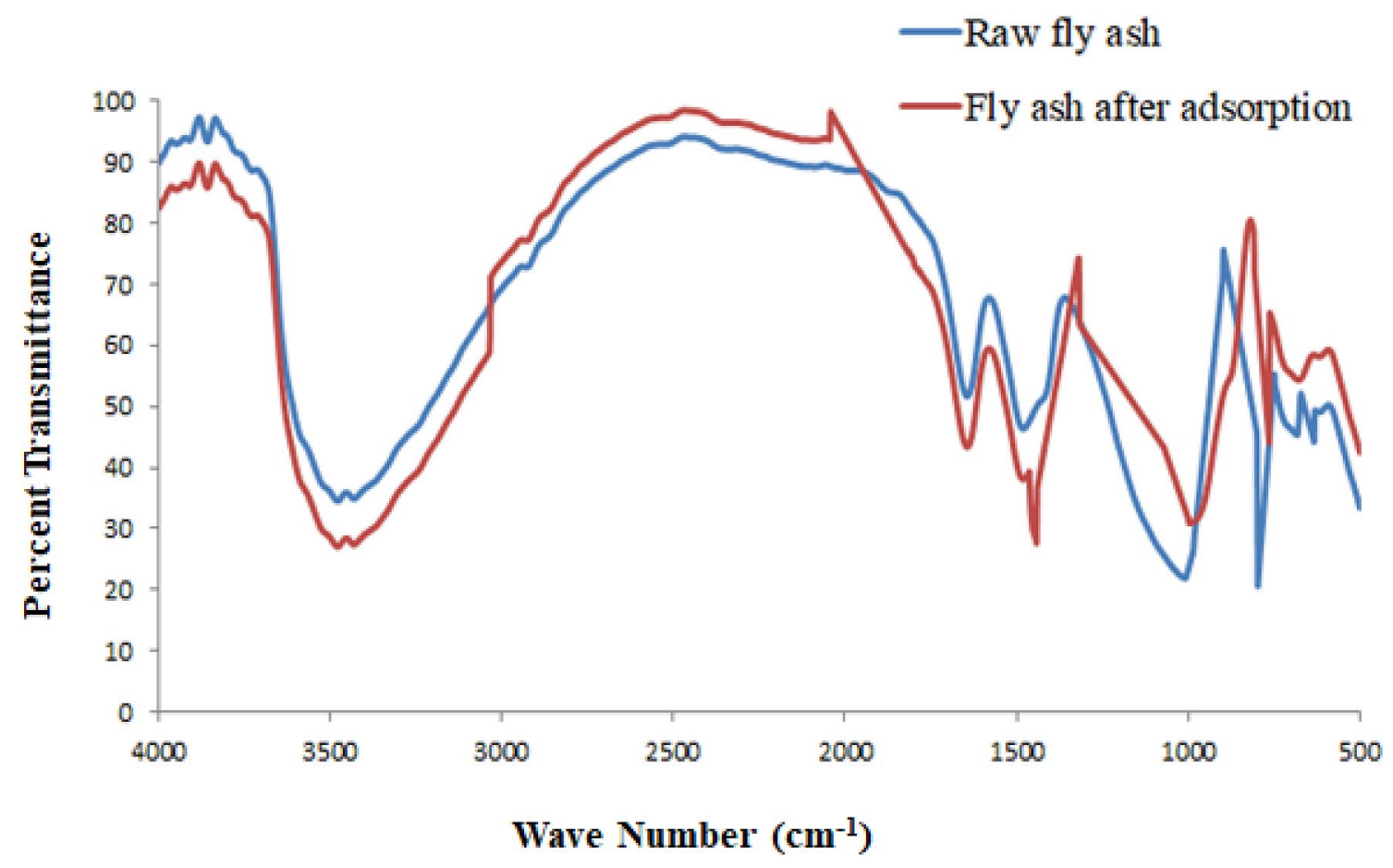

Fig. 6 FTIR spectra of the raw fly and fly ash after adsorption

Table 5 Actual and predicted values of copper uptake and removal efficiency by fly ash based on CCD matrix

\begin{tabular}{|c|c|c|c|c|c|c|}
\hline \multirow[t]{2}{*}{ Run } & \multirow[t]{2}{*}{ Point Type } & \multirow[t]{2}{*}{$\begin{array}{l}\mathrm{X}_{1}: \text { Initial copper con- } \\
\text { centration }(\mathrm{mg} / \mathrm{L})\end{array}$} & \multirow[t]{2}{*}{$\mathrm{X}_{2}: \mathrm{pH}$} & \multirow[t]{2}{*}{$\begin{array}{l}\mathrm{X}_{3}: \text { Fly ash dos- } \\
\text { age }(\mathrm{g} / \mathrm{L})\end{array}$} & \multicolumn{2}{|c|}{$\begin{array}{l}\text { Y: Removal Efficiency } \\
(\%)\end{array}$} \\
\hline & & & & & Actual & Predicted \\
\hline 1 & Fact & 27.5 & 3 & 65 & 50 & 49 \\
\hline 2 & Center & 35 & 4 & 50 & 51 & 51 \\
\hline 3 & Axial & 50 & 4 & 50 & 32 & 32 \\
\hline 4 & Fact & 27.5 & 3 & 35 & 40 & 39 \\
\hline 5 & Axial & 35 & 6 & 50 & 89 & 86 \\
\hline 6 & Fact & 42.5 & 5 & 35 & 50 & 52 \\
\hline 7 & Fact & 42.5 & 3 & 35 & 17 & 16 \\
\hline 8 & Axial & 35 & 4 & 20 & 33 & 32 \\
\hline 9 & Center & 35 & 4 & 50 & 51 & 51 \\
\hline 10 & Fact & 27.5 & 5 & 65 & 74 & 76 \\
\hline 11 & Axial & 35 & 4 & 80 & 63 & 63 \\
\hline 12 & Axial & 20 & 4 & 50 & 59 & 58 \\
\hline 13 & Axial & 35 & 2 & 50 & 21 & 23 \\
\hline 14 & Center & 35 & 4 & 50 & 51 & 51 \\
\hline 15 & Fact & 42.5 & 5 & 65 & 71 & 73 \\
\hline 16 & Center & 35 & 4 & 50 & 51 & 51 \\
\hline 17 & Center & 35 & 4 & 50 & 51 & 51 \\
\hline 18 & Fact & 42.5 & 3 & 65 & 31 & 30 \\
\hline 19 & Fact & 27.5 & 5 & 35 & 58 & 60 \\
\hline 20 & Center & 35 & 4 & 50 & 51 & 51 \\
\hline
\end{tabular}


using the CCD model by conducting 20 experiments and presented in Table 5. Based upon the calculation of regression coefficient copper removal efficiency in terms of coded factor is modeled as:

$$
\begin{aligned}
\text { Removal Efficiency }= & 50.82-6.69 X_{1}+15.69 X_{2}+7.56 X_{3} \\
& -1.47 X_{1}^{2}+0.91 X_{2}^{2}-0.84 X_{3}^{2} \\
& +3.88 X_{1} X_{2}+1.13 X_{1} X_{3}+1.63 X_{2} X_{3}
\end{aligned}
$$

Statistical significance and model adequacy of the predicted model has been analyzed by employing the ANOVA and presented in Table 6. As evident from this table, the model F-value is 201.25 , confirming the model is very much significant. Only a $0.01 \%$ chance that a model F-value this large could occur due to noise. This model also has a very low probability value ( $p>F$ value less than 0.0001 ), which implies that model terms are significant. The adequate precision value of this model's is 54.97, indicating an adequate signal of the model. For a significant model, this should be greater than 4 . In this study, $X_{1}, X_{2}$, $X_{3}, X_{1}^{2}, X_{2}^{2}, X_{3}^{2}, X_{1} X_{2}$, and $X_{1} X_{3}$ are significant model terms as their "prob $>F^{\prime}$ "values are less than 0.0500 while other terms are not significant, (In this case, only $\mathrm{X}_{2} \mathrm{X}_{3}$ is not significant.) The $R^{2}$ value of the model is 0.995 , indicates that this model could not explain only $0.5 \%$ of the total variation. In this model, the predicted $R^{2}$ value (0.9544) shows a reasonable agreement with the adjusted $R^{2}$ value (0.9896), which indicates all the terms depicted in this model are very significant. These statistical values indicate that this statistical model can perfectly simulate this fly ash's copper adsorption behavior. It is found that the plot of Normal \% probability versus studentized residual is following a straight line, which indicates data are normally distributed (Fig. 7a). The experimental values and modelpredicted values of removal efficiency as per Eq. 5 showed a high correlation with each other and shown in Fig. $7 \mathrm{~b}$.

To study the interactive relation between the process variables and removal efficiency, the $3 \mathrm{D}$ response surface is plotted based on the predicted removal efficiency. Two process variables are varying, and the other is kept constant.

\subsection{Effect of initial copper ion concentration and fly ash dosage on removal efficiency}

Figure 8a illustrates the effect of initial copper ion concentration and fly ash dosage on removal efficiency at a contact time of $3 \mathrm{~h}$ and a $\mathrm{pH}$ of 4 . It is observed that at a particular fly ash dosage, the removal efficiency shares an inverse relationship with copper concentration as it increases with a decrease in copper concentration and vice versa. This is because, at a particular fly ash dosage, total active sites available for the metal ion sorption are constant. It is also found that removal efficiency increases with an increase in fly ash dosage. The removal efficiency increased from $48 \%$ to $62 \%$ when the fly ash dosage increased from 35 to $65 \mathrm{~g} / \mathrm{L}$ at an initial copper concentration of $27.5 \mathrm{~g} / \mathrm{L}$ and $\mathrm{pH}$ 4. The increase is attributed to the availability of metal adsorption sites $[18,39]$.

\subsection{Effect of initial copper concentration and pH on removal efficiency}

The interactive effect of different levels of initial copper concentration and $\mathrm{pH}$ of solution on removal efficiency is shown in Fig. $8 \mathrm{~b}$. It is found that the $\mathrm{pH}$ of the solution has a significant impact on removal efficiency as it plays
Table 6 Analysis of variance of the quadratic model for copper uptake

\begin{tabular}{lcrrrrr}
\hline Source & Sum of Squares & $\mathrm{df}^{\mathrm{a}}$ & Mean Square & F-value & $\mathrm{p}>\mathrm{F}$ & Remarks \\
\hline Model & 5828.02 & 9 & 647.56 & 201.25 & $<0.0001$ & Significant \\
$\mathrm{X}_{1}$ & 715.56 & 1 & 715.56 & 222.39 & $<0.0001$ & Significant \\
$\mathrm{X}_{2}$ & 3937.56 & 1 & 3937.56 & 1223.75 & $<0.0001$ & Significant \\
$\mathrm{X}_{3}$ & 915.06 & 1 & 915.06 & 284.39 & $<0.0001$ & Significant \\
$\mathrm{X}_{1}^{2}$ & 54.03 & 1 & 54.03 & 16.79 & 0.0022 & Significant \\
$\mathrm{X}_{2}^{2}$ & 20.78 & 1 & 20.78 & 6.46 & 0.0293 & Significant \\
$\mathrm{X}_{3}^{2}$ & 17.78 & 1 & 17.78 & 5.53 & 0.0406 & Significant \\
$\mathrm{X}_{1} \mathrm{X}_{2}$ & 120.13 & 1 & 120.13 & 37.33 & 0.0001 & Significant \\
$\mathrm{X}_{1} \mathrm{X}_{3}$ & 10.13 & 1 & 10.13 & 3.15 & 0.1065 & \\
$\mathrm{X}_{2} \mathrm{X}_{3}$ & 21.13 & 1 & 21.13 & 6.57 & 0.0283 & Significant \\
Residual & 32.18 & 10 & 3.22 & & & \\
Lack of Fit & 32.18 & 5 & 6.44 & & & \\
Pure Error & 0.00 & 5 & 0.00 & & & \\
Cor Total & 5860.20 & 19 & & & & \\
\hline
\end{tabular}

${ }^{\mathrm{a}} \mathrm{df}=$ Degree of freedom, $\mathrm{R}^{2}=0.9945 ;$ adjusted $\mathrm{R}^{2}=0.9896$; predicted $\mathrm{R}^{2}=0.9544$ 
$\mathbf{a}$

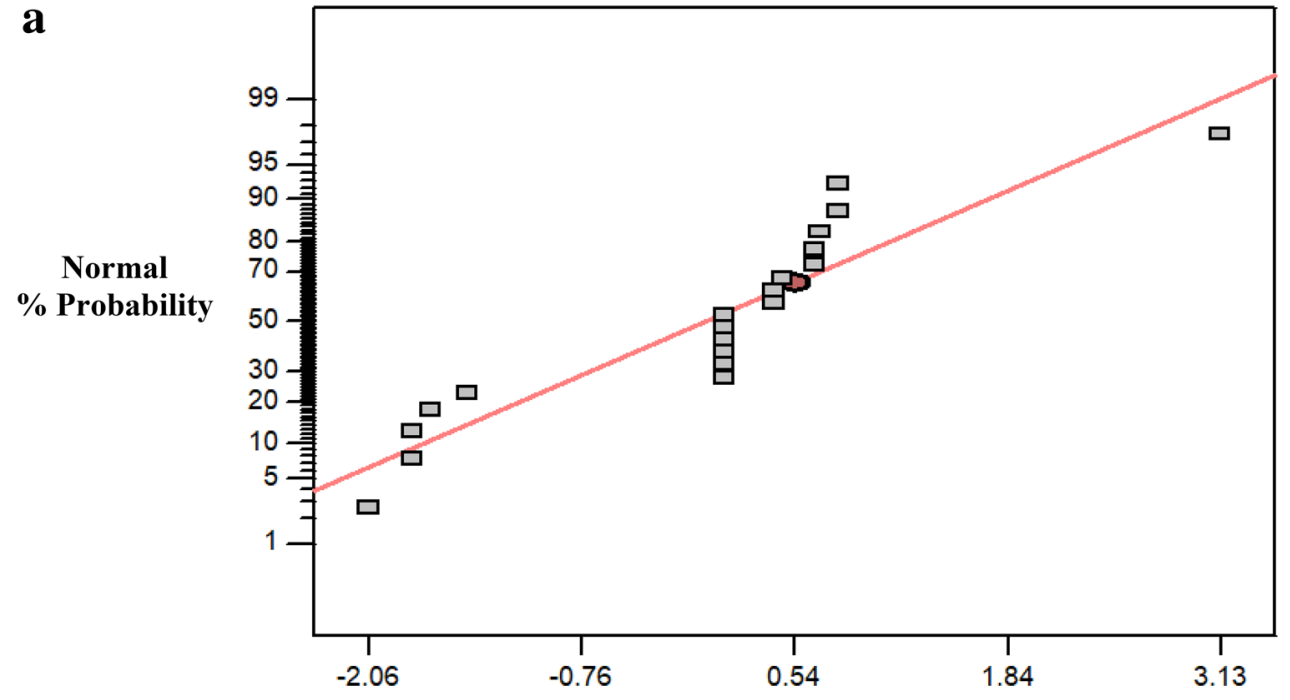

Studentized Residuals

b

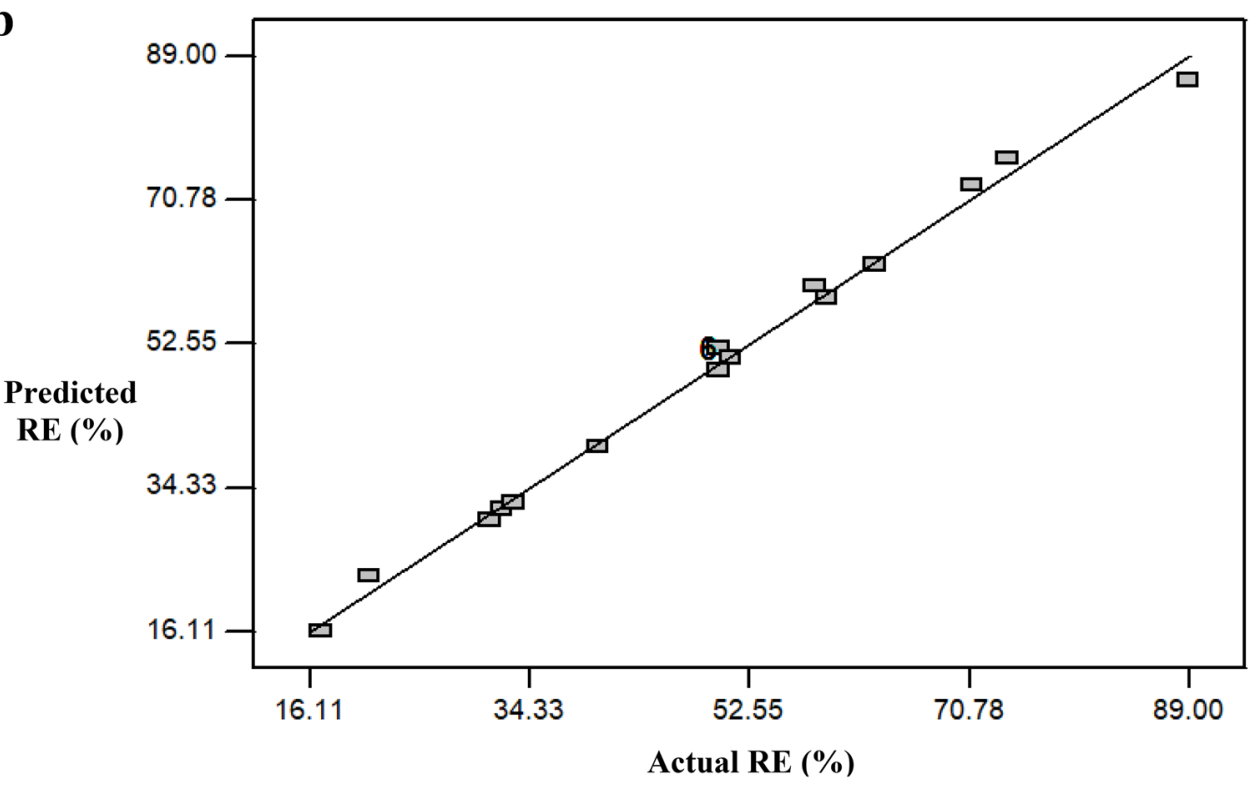

Fig. 7 Plot of a Normal \% probability vs. residual error $\mathbf{b}$ actual values vs. Predicted values

a vital role in determining the degree of ionization of metal ion and surface charge of fly ash. It is observed that removal efficiency increases significantly with the increase in $\mathrm{pH}$ and initial copper concentration. The adsorption of metal ion on the fly ash surface occurs mainly due to functional oxide groups such as silica and alumina. This fly ash's major constituents are silica and alumina. At $\mathrm{pH}$ values lower than the $\mathrm{pH}_{\mathrm{ZPC}}$, the adsorbent surface is positively charged, and for $\mathrm{pH}$ values greater than the $\mathrm{pH}_{\mathrm{ZPC}}$, the surface is negatively charged, which favors the metal ion's adsorption. It is found that the removal efficiency of this fly ash at $\mathrm{pH} 2$ is $21 \%$. In comparison, the removal efficiency is $89 \%$ at $\mathrm{pH} 6$ at a fly ash dosage and initial concentration of $50 \mathrm{~g} / \mathrm{L}$ and $35 \mathrm{mg} / \mathrm{L}$, respectively. As the $\mathrm{pH}$ values increases beyond 2.9 , fly ash's surface becomes more negatively charged as per Eq. 6, allowing copper ion to be chemisorbed.

$\mathrm{SiOH}+\mathrm{OH}^{-} \rightarrow \mathrm{SiO}^{-}+\mathrm{H}_{2} \mathrm{O}$

As observed by various researchers $[34,41]$ removal of copper at $\mathrm{pH}$ higher than $\mathrm{pH}_{\text {ZPC }}$ takes place as per the following Eq. 
Fig. 8 Three-dimensional response surface for removal efficiency as a function of $\mathbf{a}$ initial copper concentration and fly ash dosage $\mathbf{b}$ initial copper concentration and $\mathrm{pH} \mathbf{c} \mathrm{pH}$ and fly ash dosage $\mathbf{a}$

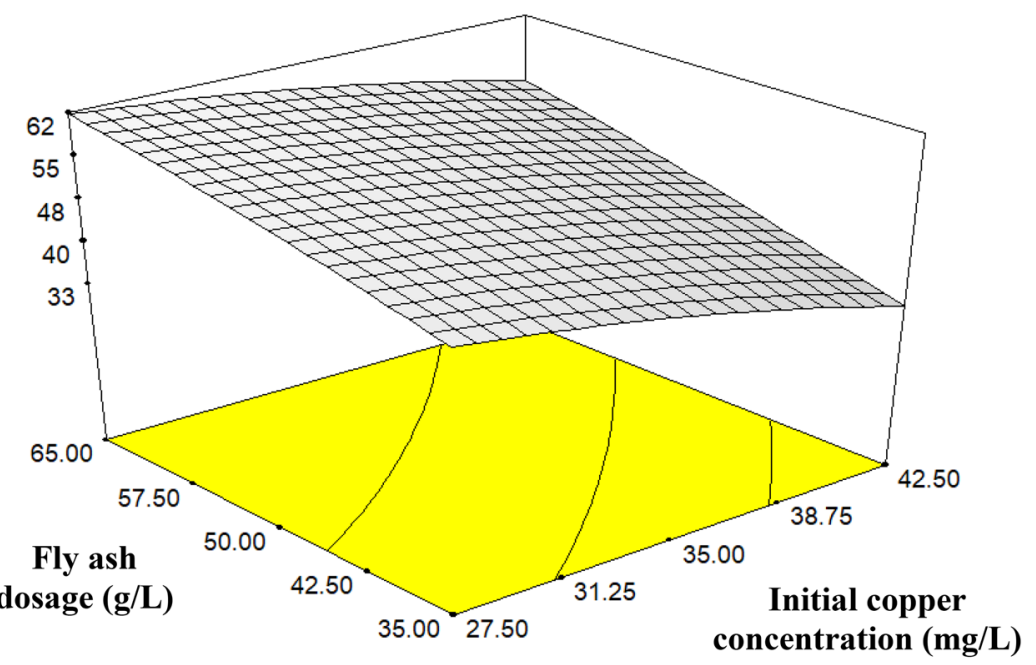

b

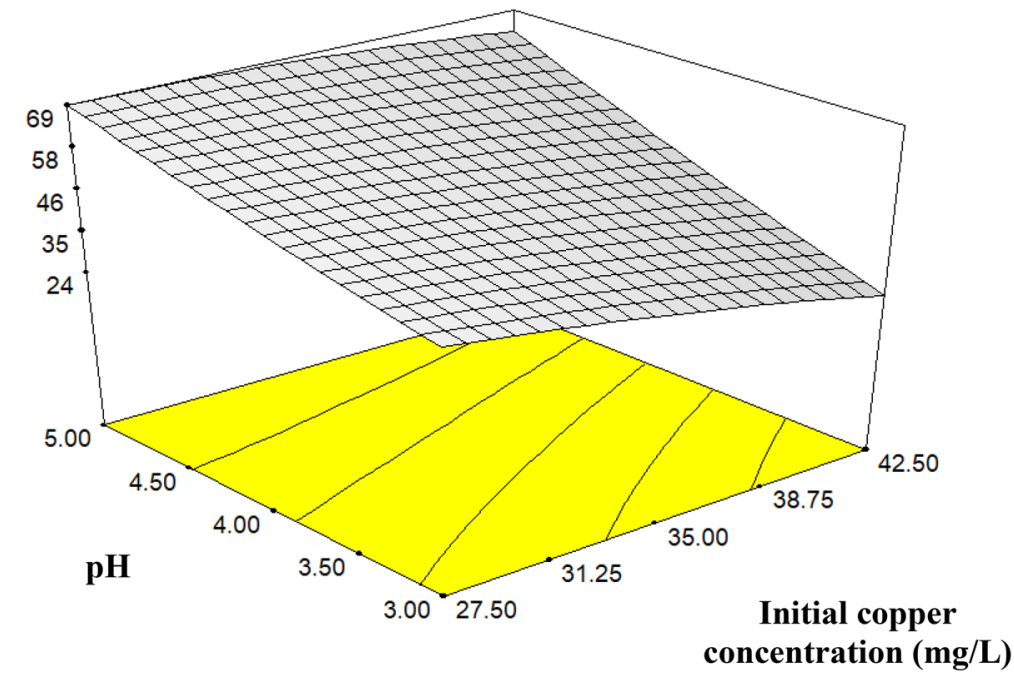

Initial copper concentration $(\mathrm{mg} / \mathrm{L})$

c D
Removal
efficiency $(\%)$ Removal
efficiency $(\%)$

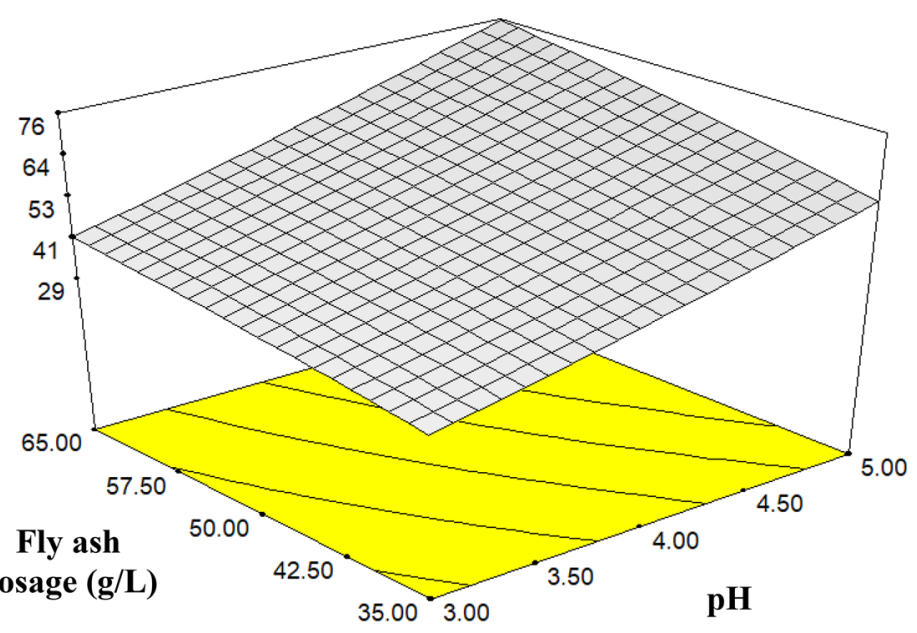


$\mathrm{Cu}^{2+}+2 \mathrm{SiO}^{-} \rightarrow(\mathrm{SiO})_{2} \mathrm{Cu}$

$\mathrm{Cu}(\mathrm{OH})^{+}+2 \mathrm{SiO}^{-} \rightarrow(\mathrm{SiO})_{2} \mathrm{CuOH}^{-}$

$\mathrm{pH}$ values lower than $\mathrm{pH}_{\mathrm{ZPC}}$ protonation of the superficial hydroxyl groups take place as per Eq. 9.

$\mathrm{SiOH}+\mathrm{H}^{+} \rightarrow \mathrm{SiOH}_{2}^{+}$

Due to repulsion caused by this positively charges hydroxyl group and $\mathrm{Cu}^{2+}$, the very low removal efficiency is observed at a $\mathrm{pH}$ value of 2 .

As suggested by various research $\mathrm{pH}$ values beyond 6 , copper ion precipitation became predominant, indicating that removal of copper ion below pH 6 is mainly accomplished by adsorption [34, 39].

\subsection{Effect of fly ash dosage and pH on removal efficiency}

Figure $8 \mathrm{c}$ shows the interactive effect of $\mathrm{pH}$ and fly ash dosage on removal efficiency at a copper concentration of $35 \mathrm{mg} / \mathrm{L}$. It has been observed that the percentage removal increases on increasing $\mathrm{pH}$ from 3 to 5 . The percentage removal rises from $28 \%$ to $55 \%$ when the $\mathrm{pH}$ increased from 3 to 5 at a $35 \mathrm{~g} / \mathrm{L}$ fly dosage. Removal efficiency also increases with an increase in fly ash dosage.

\subsection{Optimization}

The main objective of this study is to maximize copper removal efficiency. Optimization of the process variables has been carried out by using the desirability function approach. This approach is one of the most widely used methods for optimizing multiple response processes. In this method, for each response process $\mathrm{Y}_{\mathrm{i}}(\mathrm{x})$, a desirability function $d_{i}\left(Y_{i}\right)$ is assigned, and its value lies in between 0 to 1 [42]. And the overall desirability is obtained as a geometric mean of individual desirability as per the following Eq. 10:
$D(X)=\left(d_{1}\left(Y_{1}\right) \times d_{2}\left(Y_{2}\right) \times \cdots \times d_{n}\left(Y_{n}\right)\right)^{1 / n}$

where $\mathrm{n}$ denotes the number of responses. It should be noted that if any response $\mathrm{Yi}$ is completely undesirable $\left(d_{i}\left(Y_{i}\right)=0\right)$, then the overall desirability is zero.

Each process variable's desired goal is kept within range, whereas it is kept at a maximum for the response. A set of solutions with different desirability is provided by design to find out the optimum condition. Based on the solutions, an optimum condition having desirability 1.0 is chosen, and its parametric constraints with model prediction and experimental data are presented in Table 7. To find out the accuracy of the model, further experiments in triplicate are carried out at laboratory scale at optimum conditions, and the average value of the same is reported in Table 7. It is found that the experimental value shows a small deviation of $1.9 \%$. This confirms the validity of the proposed CCD model for maximizing the copper removal efficiency by fly ash.

\subsection{Comparison of adsorption capacity}

Table 8 compares this fly ash's maximum adsorption capacity with those of others. It is observed that the adsorption capacity of this fly ash is similar to other fly ashes used by different researches $[15,19,20,23-25,43,44]$. Although the fly ash used in this study exhibits low adsorption capacity compared to activated carbon and other bioadsorbent, but it is abundantly available at a very low cost. That's why it can be used as a low-cost adsorbent to treat acidic wastewater as an acid-neutralizing agent.

\section{Conclusion}

The current study is undertaken to use solid waste, namely fly ash, as a cost-effective adsorbent to remove copper from contaminated water. Fly ash is found to be a potential adsorbent for copper removal. Fly ash used in the present study is class F-type, and $\mathrm{pH}_{\mathrm{ZPC}}$ of this fly ash is 2.9. This study's main objective is to find and optimize the copper
Table 7 Parametric constraints with model prediction and experimental data

\begin{tabular}{lllllll}
\hline Constraints & Criteria & Lower limit & Upper limit & Importance & $\begin{array}{l}\text { Model- } \\
\text { predicted } \\
\text { values }\end{array}$ & $\begin{array}{l}\text { Experi- } \\
\text { mental } \\
\text { values }\end{array}$ \\
\hline $\begin{array}{l}\text { Initial metal concentra- } \\
\text { tion }(\mathrm{mg} / \mathrm{L})\left(\mathrm{X}_{1}\right)\end{array}$ & In range & 20 & 50 & +++ & 42.79 & 43 \\
$\mathrm{pH}\left(\mathrm{X}_{2}\right)$ & & & & & & \\
Fly ash dosage $(\mathrm{g} / \mathrm{L})\left(\mathrm{X}_{3}\right)$ & In range & 2 & 6 & +++ & 5.87 & 6 \\
Removal efficiency $(\%)$ & Maximize & - & 80 & +++ & 63.29 & 63 \\
\hline
\end{tabular}

${ }^{a}$ Percentage error $=1.9 \%,{ }^{b}$ Sensitivity of response over other 
Table 8 Comparison of maximum adsorption capacities of different adsorbents for copper removal from wastewater

\begin{tabular}{llll}
\hline S.N. & Adsorbents & $\begin{array}{l}\text { Maximum Adsorp- } \\
\text { tion capacity }(\mathrm{mg} / \mathrm{g})\end{array}$ & References \\
\hline 1 & Sawdust & 1.79 & {$[43]$} \\
2 & Papaya wood & 1.62 & {$[44]$} \\
3 & Fly ash & 1.39 & {$[25]$} \\
4 & Fly ash & $1.7-8.1$ & {$[24]$} \\
5 & Fly ash & $0.34-1.35$ & {$[19]$} \\
6 & Bagasse fly ash & $2.26-2.36$ & {$[15]$} \\
7 & Fly ash & $0.63-0.81$ & {$[20]$} \\
8 & Fly ash-wollastonite & 1.18 & {$[23]$} \\
9 & Fly ash & 0.64 & Present study \\
\hline
\end{tabular}

removal potential of fly ash using the RSM approach. The initial copper concentration, $\mathrm{pH}$, and fly ash dosage significantly influence the copper removal efficiency. It is found that the model obtained by CCD shows a high correlation between the experimental value (Actual value) and model-predicted value. The optimum level of $93.8 \%$ removal efficiency of copper is achieved at an initial copper concentration of $43 \mathrm{mg} / \mathrm{L}, \mathrm{pH} 6$, and fly ash dosage $63 \mathrm{~g} / \mathrm{L}$. The results of this study indicate that this fly ash can be used to treat acidic wastewater generated from industries like electroplating, fertilizer, copper smelting, acid mine drainage, etc. The copper loaded fly ash can be securely disposed of by cement fixation and may be used as a secondary construction material.

Acknowledgments The authors express their sincere thanks to the Director, Central Building Research Institute, Roorkee for his support, encouragement to publish this paper. The authors thank M/S Hindalco Industries Limited, Renukoot, for providing the fly ash free of cost for the experiment. The authors are also very grateful to the Department of Chemical Engineering, Indian Institute of Technology Roorkee, for providing technical facilities.

Author Contribution SM (PhD student) carried out all the experiments. SM, AKM, and BP performed the analysis. SM wrote the paper. $\mathrm{BP}$ and $\mathrm{AKM}$ reviewed and edited the paper. BP provided a nurturing environment and technical inputs.

Funding This research work was funded by the Council of Scientific and Industrial Research

\section{Compliance with ethical standards}

Conflict of interest The authors declared that there is no conflict of interest in the preparation of this article

\section{References}

1. Steenkamp GC, Keizer K, Neomagus H et al (2002) Copper (II) removal from polluted water with alumina/chitosan composite membranes. J Membr Sci 197(1-2):147-156

2. Naghizadeh A, Mousavi SJ, Derakhshani E et al (2018) Fabrication of polypyrrole composite on perlite zeolite surface and its application for removal of copper from wood and paper factories wastewater. Korean J Chem Eng 35(3):662-670

3. Fernández-González R, Martín-Lara MA, Blázquez G et al (2020) Hydrolyzed olive cake as novel adsorbent for copper removal from fertilizer industry wastewater. J Clean Prod 268:121935

4. Singha B, Das SK (2013) Adsorptive removal of Cu (II) from aqueous solution and industrial effluent using natural/agricultural wastes. Colloids Surf B Biointerfaces 107:97-106

5. Akbal F, Camcı S (2011) Copper, chromium and nickel removal from metal plating wastewater by electrocoagulation. Desalination 269(1-3):214-222

6. Dib A, Makhloufi L (2004) Cementation treatment of copper in wastewater: mass transfer in a fixed bed of iron spheres. Chem Eng Process 43(10):1265-1273

7. Patterson JW, Jancuk W (1977) Cementation treatment of copper in wastewater. In: Proceedings of the 32 nd Industrial Waste Conference, pp 853-865

8. Basha CA, Bhadrinarayana NS, Anantharaman N et al (2008) Heavy metal removal from copper smelting effluent using electrochemical cylindrical flow reactor. J Hazard Mater 152(1):71-78

9. Lopez FA, Martın MI, Perez C et al (2003) Removal of copper ions from aqueous solutions by a steel-making by-product. Water Res 37(16):3883-3890

10. Singha I, Sagarea AP, Comaa M et al (2013) Low levels of copper disrupt brain amyloid- $\beta$ homeostasis by altering its production and clearance. PANS Early Edition 110(36):14771-14777

11. IS 10500 (2012), Drinking Water-Specification

12. Basha CA, Saravanathamizhan R, Nandakumar V et al (2013) Copper recovery and simultaneous COD removal from copper phthalocyanine dye effluent using bipolar disc reactor. Chem Eng Res Des 91(3):552-559

13. Barakat MA, Schmidt E (2010) Polymer-enhanced ultrafiltration process for heavy metals removal from industrial wastewater. Desalination 256(1-3):90-93

14. Tang SY, Qiu YR (2018) Removal of copper (II) ions from aqueous solutions by complexation-ultrafiltration using rotating disk membrane and the shear stability of PAA-Cu complex. Chem Eng Res Des 13:712-720

15. Gupta VK, Ali I (2000) Utilisation of bagasse fly ash (a sugar industry waste) for the removal of copper and zinc from wastewater. Sep Purif Technol 18(2):131-140

16. Tsamo C, Djonga PD, Dikdim JD et al (2018) Kinetic and equilibrium studies of $\mathrm{Cr}(\mathrm{VI}), \mathrm{Cu}(\mathrm{II})$ and $\mathrm{Pb}$ (II) removal from aqueous solution using red mud, a low-cost adsorbent. Arab J Sci Eng 43(5):2353-2368

17. Sočo E, Kalembkiewicz J (2013) Adsorption of nickel (II) and copper (II) ions from aqueous solution by coal fly ash. J Environ Chem Eng 1(3):581-588

18. Hsu TC, Yu CC, Ye CM (2008) Adsorption of $\mathrm{Cu}^{2+}$ from water using raw and modified coal fly ashes. Fuel 87(7):1355-1359

19. Bayat $B$ (2002) Comparative study of adsorption properties of Turkish fly ashes: I. The case of nickel (II), copper (II) and zinc (II). J Hazard Mater 95(3):251-273

20. Lin CJ, Chang JE (2001) Effect of fly ash characteristics on the removal of $\mathrm{Cu}$ (II) from aqueous solution. Chemosphere 44(5):1185-1192 
21. Feng D, Van Deventer JSJ, Aldrich C (2004) Removal of pollutants from acid mine wastewater using metallurgical by-product slags. Sep Purif Technol 40(1):61-67

22. Chattopadhyay GC (2015) Issues in utilization of ash by thermal power plants in the country. J. Government Audit and Accounts 3:1-4

23. Crini G (2005) Recent developments in polysaccharide-based materials used as adsorbents in wastewater treatment. Prog Polym Sci 30(1):38-70

24. Ayala J, Blanco F, García P et al (1998) Asturian fly ash as a heavy metals removal material. Fuel 77(11):1147-1154

25. Panday KK, Prasad G, Singh VN (1985) Copper (II) removal from aqueous solutions by fly ash. Water Res 19(7):869-873

26. Renu Agarwal M, Singh K (2018) Removal of copper, cadmium, and chromium from wastewater by modified wheat bran using Box-Behnken design: kinetics and isotherm. Sep Sci Technol 53(10):1476-1489

27. Tetteh EK, Rathilal S, Naidoo DB (2020) Photocatalytic degradation of oily waste and phenol from a local South Africa oil refinery wastewater using response methodology. Sci Rep 10(1):1-12

28. Kiran B, Thanasekaran K (2011) Copper biosorption on Lyngbya putealis: application of response surface methodology (RSM). Int Biodeterior Biodegradation 65(6):840-845

29. Özer A, Gürbüz G, Çalimli A et al (2009) Biosorption of copper (II) ions on Enteromorpha prolifera: application of response surface methodology (RSM). Chem Eng J 146(3):377-387

30. Alinnor IJ (2007) Adsorption of heavy metal ions from aqueous solution by fly ash. Fuel 86(5-6):853-857

31. IS: 1727 (1967) Methods of Tests for Pozzolanic Materials

32. Jeffery GH, Bassett J, Mendham J et al (1988) Vogel's quantitative inorganic analysis, 5th edn. ELBS, Berlin

33. ASTM C 618 (2003) Standard Specification for Fly Ash and Raw or Claimed Natural Pozzolan for Use as Mineral Admixture in Portland cement Concrete

34. Mohan S, Gandhimathi R (2009) Removal of heavy metal ions from municipal solid waste leachate using coal fly ash as an adsorbent. J Hazard Mater 169:351-359
35. Mollamahmutoğlu M, Yilmaz Y (2001) Potential use of fly ash and bentonite mixture as liner or cover at waste disposal areas. Environ Geol 40(11-12):1316-1324

36. Li HL, Liu GL, Cao Y (2014) Content and distribution of trace elements and polycyclic aromatic hydrocarbons in fly ash from a coal-fired CHP plant. Aerosol Air Qual Res 14(4):1179-1188

37. Srivastava VC, Mall ID, Mishra IM (2006) Characterization of mesoporous rice husk ash ( $\mathrm{RHA}$ ) and adsorption kinetics of metal ions from aqueous solution onto RHA. J Hazard Mater 134(1):257-267

38. Weng CH, Huang C (2004) Adsorption characteristics of Zn (II) from dilute aqueous solution by fly ash. Colloids Surf A Physicochem Eng Asp 247(1):137-143

39. Ghosh A, Saha PD (2012) Optimization of copper adsorption by chemically modified fly ash using response surface methodology modelling. Desalination Water Treat 49(1-3):218-226

40. Visa M, Isac L, Duta A (2012) Fly ash adsorbents for multi-cation wastewater treatment. Appl Surf Sci 258(17):6345-6352

41. Tofan L, Paduraru C, Bilbia D, Rotoriu M (2008) Thermal power plants ash as sorbent for the removal of $\mathrm{Cu}(\mathrm{II})$ and $\mathrm{Zn}$ (II) ions from wastewaters. J Hazard Mater 156:1-8

42. Myers RH, Montgomery CM (1995) Response Surfaces Methodology: Process and Product Optimization using Designed Experiments. Wiley, New York

43. Yu B, Zhang Y, Shukla A, Shukla SS et al (2000) The removal of heavy metal from aqueous solutions by sawdust adsorptionremoval of copper. J Hazard Mater 80(1-3):33-42

44. Saeed A, Akhter MW, lqbal M (2005) Removal and recovery of heavy metals from aqueous solution using papaya wood as a new biosorbent. Sep Purif Technol 45(1):25-31

Publisher's Note Springer Nature remains neutral with regard to jurisdictional claims in published maps and institutional affiliations. 